\title{
Host-Region
}

\section{Safe Folklore and the Negotiation of Difference In Post-Socialist Diasporas in Newfoundland}

\author{
Mariya Lesiv \\ Memorial University
}

\begin{abstract}
Many studies of diasporas focus on (large) locales where sizable diasporic populations provide room for group formation based on a single ethnicity. Scholars often treat such regions as representative of larger units, defining hostland in broad geopolitical categories of countries and even continents. Based on ethnographic research devoted to immigrants from postSocialist Europe and Asia to the Canadian island of Newfoundland, I propose the concept of host-region to emphasize a regional perspective in diaspora studies. The overall small newcomer population and the unique socio-cultural context of the island result in regionally-specific diasporic group-building dynamics, stimulating new Newfoundlanders to expand the notion of their people beyond likeminded co-ethnics. Safe home-region folklore, namely, select cultural expressions that reinforce a sense of unity and do not cause tensions within a group, offers points of connection. However, contrary to many studies that emphasize the notion of commonality within groups, I show that difference, reinforced by continuous turbulence in the home-region, can be equally important in group-building endeavors.
\end{abstract}

Keywords: Diaspora; migration, ethnicity; host-region; safe folklore; folk group; post-Socialism

Résumé: De nombreuses études sur les diasporas se concentrent sur les (grandes) régions où d'importantes populations diasporiques permettent la formation de groupes fondés sur une seule ethnicité. Les chercheurs traitent souvent ces régions comme représentatives d'unités plus vastes, définissant les terres d'accueil dans de larges catégories géopolitiques de pays et même de continents. À partir d'une recherche ethnographique consacrée aux immigrants de l'Europe et de l'Asie post-socialistes sur l'île canadienne de Terre-Neuve, je propose le 
concept de région d'accueil pour mettre en évidence une perspective régionale dans les études sur les diasporas. La faible population globale des nouveaux arrivants et le contexte socio-culturel unique de l'île entraînent une dynamique de constitution de groupes diasporiques spécifiques à la région, ce qui incite les nouveaux Terre-Neuviens à élargir la notion de leur peuple au-delà des co-ethnies apparentées. Le folklore sécuritaire de la région d'origine, à savoir des expressions culturelles choisies qui renforcent un sentiment d'unité et ne provoquent pas de tensions au sein d'un groupe, offre des points de connexion. Cependant, contrairement à de nombreuses études qui mettent l'emphase sur la notion de similitudes au sein des groupes, je montre que la différence, renforcée par les turbulences continues dans la région d'origine, peut être tout aussi importante dans les efforts de construction d'un groupe.

Mots-clés: Diaspora; migration; ethnicité; région d'accueil; folklore sécuritaire; groupe folklorique; post-socialisme

cholars of diasporas often focus on representative settings where diasporic
presence is prominent, allowing communities to form around single ethnicities. ${ }^{.}$They also frequently treat such locales as representative of hostlands defined in broad geopolitical categories of countries and even continents. I propose the concept of host-region to emphasize a regional perspective in diaspora studies and to draw attention to less prominent diasporic contexts. Readers are invited on an ethnographic tour of diasporic life on the Canadian island of Newfoundland, where they will meet settlers who once lived on other side of the Iron Curtain, namely, in the former Socialist countries of Europe and Asia.

Newfoundland is a small place that is widely perceived as homogeneous, with a population of predominantly English and Irish descent. The overall small diasporic demographic and the unique socio-cultural context of the island stimulate Newfoundlanders from the former Socialist world to expand the notion of their people beyond particular ethnicities, and reengage with their shared past. ${ }^{2}$ It is not an easy endeavour, especially considering continuous turbulence in the home-region. "Safe" folklore, while a dynamic category, offers points of connection. However, contrary to folkloristic studies that emphasize commonality within folk groups, I show that difference can sometimes be equally important and serve as a group-building element rather than a dividing factor. 
In 20II, my family and I relocated from Edmonton, Alberta, a western Canadian city with a sizable, diverse and politically active Ukrainian diaspora, to St. John's, the provincial capital of Newfoundland and Labrador. Whenever asked if there is a large Ukrainian community on our island, my husband, a fourth generation Ukrainian Canadian, and I, an immigrant from post-Soviet Ukraine, share a similar joke, responding: "Yes, and all Ukrainians of Newfoundland live in our house." Although hardly the literal truth, this nonetheless reflects some regionally unique diaspora dynamics. While looking for "my people" on the island, I soon realized how I gradually expanded the very notion of my people to include individuals from places far beyond Ukraine. Now, whenever I meet Newfoundlanders from any of the fifteen former Soviet republics, our conversations evolve around the notion of nashy in Newfoundland. Nashy translates from Russian as our people. In Newfoundland, it is often used interchangeably with the term "Russians" that reflects a shared Russian language and Soviet background rather than Russian ethnicity.

Such personal encounters led me to the following research questions: How does the shared past shape identity- and group-building endeavors in a small place not associated with a prominent diasporic presence? How do individual home countries' post-Socialist political situations influence diasporic life in a setting that offers a very limited number of like-minded co-ethnics? This work is based on in-depth semi-structured interviews, informal conversations, and participant observation at numerous public and private events. ${ }^{3}$ As a folklorist, I was especially interested in diasporans' creative expressive culture. Individuals whose voices are extensively cited were invited to comment on my interpretations, with their feedback further incorporated into an additional layer of discussion. This reflects the principles of "reciprocal ethnography," a "multi-layered, polyphonic dimension of dialogue and exchange" meant to be a more democratic way of representing voices in an ethnographic study (Lawless 1993, 60).

Although there are ongoing discussions regarding the concept of diaspora and the types of groups to which it applies (for example, Cohen 2008; Dufoix 2008; Tölölyan 2012), the multidisciplinary field of diaspora studies has expanded its focus beyond communities associated with traumatic resettlement such as Jews and Armenians. The concept now often embraces any people who have relocated from their places of origin, and it is in this latter sense that I use it in the present study. However, following sociologist Rogers Brubaker's approach, I do not treat diaspora in "substantialist terms as a bounded entity" but as a situational and dynamic category (Brubaker 2005, I2). The conceptual 
differences between specific types of migrants such as refugees and immigrants, while important, are not relevant to the present discussion. I refer to all individuals from post-Socialist Eurasia as newcomers, new Newfoundlanders, postSocialist settlers and diasporans interchangeably.

While focusing on the local, this research embraces broader influences because "local culture is always marked and is always part of a larger-than-local context" (Shuman 1993, 345). Numerous studies of diasporas show, albeit through the prism of varying methodological and theoretical frameworks, that diasporic experiences cannot be viewed outside of broader historical, political, social, cultural and economic processes (for example, Bulmer and Solomos 20II; Chowdhury and Akenson 2016; Clifford 1994; Gray 2004; Laguerre 2006; Levy and Weingrod 2005; Rozen 2008; Smith and Stares 2007).

\section{Diasporic Groups and Contexts}

Since this study is devoted to diasporic group formations in practice, the concept of group plays a key role in understanding such processes. The concept is especially important in folkloristics since folklore implies communication and sharing. Utilizing the definitions of folk group offered by Dan Ben-Amos (1972), Alan Dundes (1965), and Barre Toelken (1979) and drawing on performance and social network theories, Dorothy Noyes (1995) sees group formation processes as a dialogue between the "empirical network of interactions in which culture is created and moves, and the community of the social imaginary that occasionally emerges in performance" (452). Noyes shows that while pre-existing markers can indeed form the basis for a group, they should not be essentialized; in reality, groups are shaped by complex situational webs of networks based on shared experiences and imaginaries (1995). Noyes and other folklorists recognize the dynamic complexities and heterogeneity in group-building endeavors. However, whether implicitly or explicitly, they still emphasize markers of commonality or "linking factor[s]" (Dundes 1965) within groups as the most important aspects in such processes. Differences, or "differential identities" (Bauman 1972) are usually emphasized when it comes to inter-group dynamics rather than relationships within groups.

Like many other social units, diasporas form around "linking factors." Some scholars identify diasporic groups on the basis of relatively broad, often overlapping, shared characteristics such as race (for example, Bruner 1996; and Green 1997) or religion (for example, Moghissi 2006). However, it is the 
notion of ethnicity that appears to be the most prominent "linking factor" in diaspora formation initiatives. This is reflected in studies that, while varying in approach, are devoted to groups that share the same ethnicity. Examples include Finnish (e.g., Köngäs-Maranda 1980), Greek (e.g., Georges 1980; Tziovas 2016), Indian (e.g., Parekh, Singh and Vertovec 2003), Irish (e.g., Akenson 1996; and Bielenberg 2000), Italian (e.g., Ruberto and Sciorra 20I7), Mexican (e.g., Lattanzi Shutika 20II) and Ukrainian (e.g., Klymasz I973; Nahachewsky 2002) migrants and diasporic communities.

Studies on migration and diasporas hailing specifically from the former Socialist countries of Europe and Asia also focus predominantly on ethnic groups. Even those diasporas connected with the former multi-national states of Yugoslavia and the Soviet Union often appear to form along ethnic lines. Yugoslavian examples include the Croatian diaspora in Canada (Winland 1995), and Bosnian communities in Australia, the United States, and Western and Central Europe (Valenta and Ramet 20II).

The broader concept of post-Soviet diaspora circulates in studies devoted to communities associated specifically with the former USSR (for example, Pechurina 20I7, 29-45). However, it is often understood as Russian-speaking diaspora embracing immigrants who either self-identify as Russian or speak Russian as their primary language (for example, Fialkova and Yelenevskaya 2013). The majority of post-Soviet diasporic formations appear to be single ethnicitybased. Examples include Azerbaijanis in Russia, the Middle East, and Western countries (Iunusov 2003), Russians in the USA (Isurin 20II; Kishinevsky 2004), Israel and Germany (Isurin 20II), Russian-speaking Jews in Israel, Germany, North America (Remennick 20I2) and specifically in the United States (Laitin 2004), Ukrainians in North America (Satzewich 2002, 190-213) and specifically in the United States (Solari 20I7, I25-2I8), as well as in Italy (Solari 20I7, 25-I23).

Single ethnicity-based studies are the result of the contextual particularities of representative diasporic centres. Many such locales have what anthropologist Natalia Khanenko-Friesen (2017) calls "old diasporas" or established pre-existing ethnic venues (48). A number of my interlocutors, especially immigrant professionals who had lived in other (larger) areas of North America prior to their relocation to Newfoundland, spoke about their previous diasporic lives within such single ethnicity-based groups. Their experiences included participating in stage performances of the Croatian community in Hamilton, Ontario, and acting in the Belarusian theatre in Toronto. While the notion 
of ethnicity is complex and ethnic groups frequently experience tensions due to their internal diversity (for example, Khanenko-Friesen 20II, 289-326; Satzewich 2002, 190-213), representative diasporic centres provide a platform for a negotiation of such diversity along ethnic lines.

Prior to inviting readers to the non-representative diasporic setting of Newfoundland, allow me to introduce the post-Socialist contexts from which the newcomers arrived. As in the case of diasporic settlements elsewhere, their local presence is rooted in major global shifts.

\section{Coming From: Home-Region}

The collapse of the Socialist regime in 1989 brought dramatic changes significantly redrawing the map of parts of Europe and Asia. Prior to this, approximately 48 million people in the region lived outside of their ethnic countries of birth (Heleniak 2017, I2). For example, approximately 25 million ethnic Russians resided within the Soviet Union but outside of Russia. As many scholars of the post-Soviet space observe, with the dissolution of the USSR these people no longer represented the dominant ethnicity in their countries of residence, but were transformed into minority diaspora groups (Kolstoe 1995; Kolstø 200I; Lauristin and Heidmets 2002), experiencing dramatic social changes (Chinn 1996; Kolstoe 1995; Kolstø 200I; Lauristin and Heidmets 2002; Shlapentokh et al. 1994). New minority-related situations led to the psychological trauma of particular individuals and groups, and also to military unrest in many parts of the region.

The collapse of the Socialist regime especially affected the multi-national former Soviet Union and Yugoslavia. Despite Socialist internationalization initiatives implemented in both countries, this political shift led to nationalization endeavours closely linked to the growth of ethnic consciousness. Viewed by some as the "cold" versus "hot" ethnicity continuum (Zabrodskaja and Ehala 20I4), ethnic identity awareness and inter-ethnic conflicts sparked and intensified in various former Socialist areas at different times. The 1990-92 Transnistria War between the pro-Russian self-proclaimed Republic of Transnistria and the remainder of Moldova, populated predominantly by Moldovans, is one example from the former USSR (for example, Cojocaru 2006).

Yugoslavia, in turn, endured the Yugoslav Wars, a series of brutal military conflicts between I99I and 200I (for example, Baker 2015; Naimark and Case 2003). The outbreak of those clashes is also partly associated with the fear for the destiny of ethnic minorities living outside of their ethnic homelands. This 
was especially true for many Serbs, whose dominant position in Yugoslavia was similar to that of their Russian counterparts in the USSR (Stokes 2005, 3). The present-day Ukraine-Russia crisis that began with Russia's annexation of Crimea in 2014 illustrates that political and military tensions in the postSocialist world are still emergent and ongoing (for example, Yekelchyk 2015).

\section{Coming To: Host-Region}

Immigration to Newfoundland from the former Socialist countries began in the mid I980s, immediately preceding the collapse of the Socialist system. At that time Gander International Airport served as a refueling stop for flights from those countries (Cawley 1985). The large number of asylum seekers who chose to disembark from their flights (Gilad 1990, 25), contributed to the town of Gander's reputation as the "defection capital" of Canada (Beltrame 1984, 40). In the early I990s, military conflicts and the overall political and economic uncertainty caused by the fall of the Socialist system subsequently resulted in large waves of defectors from the former Soviet Union and other post-Socialist countries, especially Bulgaria (CBC News 20I6). The Yugoslav Wars brought refugees from the former Yugoslavia, including Bosnia and Herzegovina and Kosovo. In recent decades, the island has also attracted immigrant professionals and international students from post-Socialist Europe and Asia.

In Newfoundland, newcomers do not simply find themselves in a different country. They face a unique regional setting shaped by various geographical, historical, political, social and economic influences (for example, Jackson Anderson 2012; Overton 1996; Pocius 2000; Thorne 2007). Newfoundland is widely perceived as culturally homogeneous, displaying a strong sense of distinct local identity. An intriguing indicator of many Newfoundlanders' attachment to place is that the term "diaspora" has been increasingly applied to out-migration from Newfoundland (Delisle 2013, 9-27). Upon first meeting, Newfoundlanders often try to place strangers "in the large web of people they know" in order to determine to whom they are connected and where they "belong" (Jackson Anderson 2012, I). Family and community ties are especially strong among native Newfoundlanders, often resulting in the exclusion of newcomers. Firmly established social circles preclude the need for Newfoundlanders to seek further social engagement (Jackson Anderson 2012, 22I-22).

Considering socio-cultural particularities, harsh climate and limited economic prospects on the island, only a small number of newcomers make Newfoundland their permanent home. Many begin seeking professional 
opportunities in other parts of Canada soon after arrival in Newfoundland. According to Adnela, an immigrant from Bosnia and Herzegovina, there are presently a few hundred newcomers from the former Yugoslavia, including temporary residents (field notes, March 20I9). ${ }^{4}$ This estimate is based on Adnela's observations as a co-owner of the Balkan Kitchen restaurant, the centre of diasporic life for people from the former Yugoslavia. However, some particular countries and ethnicities of the former Socialist region are represented by significantly smaller numbers. According to Newfoundland-based Bulgarian sculptor Luben Boykov, out of approximately 3,00o Bulgarians who disembarked in Gander in the 1990s, only about 30 stayed in Newfoundland (CBC News 2016). Similarly, Sofia and David estimate that out of approximately 2,00o asylum seekers from Moldova, only a few families remained (David and Sofia, interview, Oct 23, 2016). Botir is certain that he, two other adults, and their children are the only Uzbeks in the St. John's vicinity (Botir, interview, March 2019).

Contextual dynamics on the island show the importance of considering where newcomers come "to" in specific terms, rather than broad geopolitical categories. It is not only the locals who understand the uniqueness of the island within the broader social fabric of Canada. The same kind of understanding is reflected in diasporans' everyday speech. While occasionally referring to Canada, many of my interlocutors referred specifically to Newfoundland or the island when speaking about their new place of residence.

\section{Building Groups: Diasporic Similarity-Difference Continuum}

While common ethnicity is a relevant factor when it comes to communitybuilding endeavors, expressions of ethnic identities often take place in small private settings. These manifestations are beyond the scope of the present paper that, in turn, focuses on larger-scale public venues. Olga, an ethnic Russian, expressed regret that no large public events are presently organized by "our people" on the island saying: "When it's just a few families that gather for an occasion it turns into a simple dinner party but when many people are involved it's a real celebration" (Olga, interview, May 2019).

Due to the overall small diasporic population, the lack of "old diasporas," and the transitory nature of many people's residency on the island, no formal diasporic institutions have been established. Outside of their private settings, the majority of my research participants belong to multiple social circles based on varying (non-diasporic) "linking factors." Even though the shared Socialist 
past is only one point of connection, it appears to be distinct and important. Due to the absence of institutions with formal leadership and membership, frequent and structured activities do not take place. Instead, the past-related regional identities are communicated through occasional events and venues that allow the formation of temporal diasporic groups. It is solely the enthusiasm of select individuals and their creative initiatives that shape the public social lives of post-Socialist settlers. Attendees of diasporic gatherings may or may not have lasting relationships with core organizers outside of particular events. ${ }^{6}$

Overall, organizing "our people" in Newfoundland on a large-scale is not an easy task. In addition to cultural, religious and ethnic differences, new settlers carry their individual country's historical baggage associated with the collapse of the Socialist regime. Nonetheless, while dramatic past and present-day political realities often cause divisions in the settlers' places of origin, the Newfoundland context stimulates them to seek points of connection. Such unifying endeavors require a high degree of what some anthropologists conceptualize as "everyday diplomacy," challenging an earlier perception of diplomacy as predominantly the realm of a political elite formally trained to represent nation-states in world affairs (Marsden, Ibañez-Tirado and Henig 20I6). They observe diplomatic endeavours among "different people in a variety of domains of action and experience" (Marsden, Ibañez-Tirado and Henig 20I6, 7). Seeking points of connection within temporal groups implies making simultaneous efforts to overcome differences.

The concept of "difference" frequently circulates in the field of diaspora studies. Amitava Chowdhury points out that one of the elements that imparts the term "diaspora" with meaning "is a realization that diasporas signify difference" (Chowdhury 20I6, xi). He continues:

The stated difference operates along two axes - difference of the diasporans from the host societies; and, difference of the diasporans from the emigrating zones, that is, the place of origin. Diasporic difference along these two registers leads to a particular way of belonging in the world. (Chowdhury 20I6, xi)

In the host-region of Newfoundland, difference is a very complex entity. While both axes identified by Chowdhury apply to the present work, my research shows the necessity to also recognize and problematize the notion of difference within the diasporas. Diasporic difference appears to be flexible and situational. It is heuristically useful to look at it and its opposite-commonality-as 
a continuum. On the diasporic commonality-difference continuum, people who come from the same region with a shared Socialist past are more similar and familiar and, thus, placed in closer cognitive proximity than the Newfoundlandborn majority.

While scholarship dealing with group formation processes emphasizes "linking factors" or markers of commonality, post-Socialist settlers in Newfoundland reveal that difference within groups can be equally significant. ${ }^{7}$ In order to embrace home-region commonalities rooted in their shared past, new Newfoundlanders need to first reflect on their home-region divides, making a cognitive effort to reconcile them. Thus, theoretically, difference also serves as a group-building element rather than a divisive factor within groups. Without the overcoming of difference, post-Socialist diasporic groups would not form.

A 1999 CBC interview with Eldin and Lido, refugees from the former Yugoslavia, conveyed the newcomers' condemnation of the NATO military operation against the Federal Republic of Yugoslavia during the Kosovo war. While expressing their negative view of Canada's involvement in the operation, Eldin and Lido shared the following sentiment: "We would be enemies if we stayed there. Definitely, here we'd play guitars together, over there we'd be crashing the same guitars over each other's heads. We'd be the enemy really" (CBC News 1999). This reveals individual diplomatic efforts to reflect on homecountry differences to create a sense of unity in the host-region. The following examples illustrate larger group-building endeavors.

\section{Food and the Balkan Kitchen}

Select forms of home region folklore that communicate commonality become an effective vehicle for "everyday diplomacy" in the host-region of Newfoundland. They play an important role when it comes to community life and temporal diasporic groups that form beyond the small private circles of co-ethnics. Traditional foodways represent one of the most prominent examples. Eldin and Adnela, a family couple (introduced individually above) who own the Balkan Kitchen restaurant, use the traditional cuisine of various nations of the former Yugoslavia as a marketing strategy. For example, on I9 May 2018 the restaurant featured "Slavonia Night At Balkan Kitchen." Slavonia is a culturally distinct region of Croatia located in the eastern part of the country. The couple invited their Slavonian friend Josip to prepare a traditional Čobanac stew and Makovnjaca rolls and to deliver a short presentation about the region to customers. This diplomatic effort by the owners can be especially appreciated if one considers 
that their home country of Bosnia and Herzegovina experienced the 1992-94 Croat-Bosniak War. Moreover, Eldin and Adnela, Bosnian Muslims, served Čobanac stew, a pork-based dish from Catholic Croatia. While Slavonia Night was Eldin and Adnela's idea, in order to embrace it as part of their common former Yugoslav/Balkan culture, both the owners and Josip had to reconcile the religious divides and the turbulent realities in their home-region.

I do not mean to idealize diasporic experiences or to produce what folklorist Pauline Greenhill (2002) calls "ethnography of niceness" (227), where some scholars "may choose to downplay 'negative' material in a paternalistic effort to 'protect' those with whom they have worked" (229). A fieldwork encounter at Balkan Kitchen that reflects the principles of "reciprocal ethnography" reveals that, like any other group, the post-Socialist diasporans experience tensions.

On I March 2019, as I was dining at Balkan Kitchen, Eldin inquired about the details of my research. While describing the project, I mentioned that the diplomatic initiatives at Balkan Kitchen appeared to ideally illustrate how the unique socio-cultural context of Newfoundland stimulated newcomers from the former Yugoslavia to reconcile their turbulent past. Eldin listened carefully and then reacted with his characteristic wit and sense of humor. He responded that, while he usually disagreed with everybody, my interpretation of diasporic interaction on the island sparked an interest in him and he agreed with it... "but not quite." Eldin skeptically insisted that it was Canadian law that made his people treat each other in a civil way rather than their genuine desire to reconcile the past. He said that when a table of Serbs and a table of Kosovans were in the restaurant at the same time he could feel tension in the air. Kosovo declared independence from Serbia in 2008, an independence that Serbia does not recognize (for example, Bieber 2015).

I clarified to Eldin that "everyday diplomacy" does not necessarily imply any profound transformation in us as people. As anthropologist Marsden illustrates, everyday diplomats do not become traitors by changing their affiliations, loyalty or overall values. Instead, they manage to blur boundaries in order to achieve particular goals or meet certain needs (Marsden 2016, 69). According to Adnela, 60 percent of Balkan Kitchen's customers are former Yugoslavs (field notes, March 2019). The very fact that representatives of various nations of the former Yugoslavia come to the restaurant on a regular basis, understanding that the chance of meeting their home country enemies is high, does not indicate that they have changed their views on political matters in their home-region. It rather suggests that the diasporans selectively overcome home-region 
differences associated with animosity while diplomatically embracing cultural commonality. The atmosphere at Balkan Kitchen provides a rare sense of home in the larger more foreign context. Eldin agreed, and I sighed with relief.

\section{Post-Soviet New Year}

Between the years of 2006 and 20I2, post-Soviet settlers annually celebrated New Year in St. John's. Despite their specific ethnicities, countries of origin, and current political views, many former Soviet citizens regard New Year as one of the most beloved holidays. Russian folklorist Svetlana Adonyeva (2016) traces the roots of Soviet New Year to pre-Soviet times. However, she recognizes that the Soviet version represents a new construction in terms of content and meanings (Adonyeva 2016, I68-193). In this regard, the New Year ritual can be considered part of a social engineering project Russian studies scholar Frank Miller (1990) labels "folklore for Stalin." Although Miller (1990, xiii) focuses on oral genres rather than ritual practices, New Year fits the category he describes as "artificial folklore" based on traditional genres, created to propagate the Soviet government's agenda during the Stalin era.

Following the October Revolution, Christmas and New Year celebrations were forcibly banned, considered backward-oriented traditions that carried dangerous religious connotations (Kruglova and Savros 2010, 7). However, an article from 28 December 1935 in the newspaper Pravda changed the course of New Year's history again. The article stressed the necessity to organize collective New Year parties for children (Adonyeva 20I6, I78-I79). These events were soon disseminated across the entire Soviet Union, from "the Grand Kremlin Palace to the GULAG camps, from Azerbaijan to Chukotka" (Dushechkina 2003). Soviet New Year parties also reached public and domestic adult spaces, and remain popular to the present. While in home settings it is celebrated on the night of 3I December, public events are scheduled at varying times around the actual beginning of the new year. The annual Newfoundland-based celebrations took place on 25 December, as it is Christmas day on the Gregorian calendar and, thus, a statutory holiday in the province. According to Alena and Ihar, immigrants from Belarus and the core event organizers, peak attendance-I44 people-was reached in 2007 (Alena and Ihar, interview, May 2015). The $201 \mathrm{I}$ and 2012 parties that I participated in involved 60 to 70 people.

The Newfoundland events were conducted in Russian, the main language shared by former citizens of the Soviet Union. They maintained many traditional Soviet motifs, including a Master of Ceremonies who followed a prepared script. 
The script presented serious and humorous greetings, a variety of contests and short interactive theatrical performances. Ded Moroz (Grandfather Frost) and his granddaughter Snegurochka were central characters of the parties. The 2012 event also demonstrated the significant role television played in Soviet and post-Soviet New Year celebrations, illustrating its status as a "media holiday" (Huxtable at al. 2017). The Russia-based television program Goluboi Ogoniek (Little Blue Flame), "an extravaganza lasting several hours, featuring comedy, celebrities, chat and cabaret" became an essential component of New Year celebrations (Huxtable at al. 20I7, 62).

In the spirit of Little Blue Flame, the 2012 Newfoundland New Year's party featured parodies of Soviet/Russian pop stars. Two organizers dressed up as Alla Pugacheva, an iconic Soviet and Russian singer, and Andriy Danylko, a Ukrainebased performer who was very popular in Russia at the time and best known for his drag persona Verka Serduchka. The parodists danced to recorded songs by Pugacheva and Serduchka that were familiar to the majority, if not everyone, in the audience. The Newfoundland parodies closely resembled the actual artists, including their characteristic dress and gestures performed in a grotesque way. They created an overall aura of shared positivity, fun, and hysteric laughter.

Perhaps the biggest hit was a parody of Buranovskiye Babushki (Buranovo Grannies). Known for its distinct folk flavor, the actual Russian ethno-pop band is comprised of eight elderly women from the village of Buranovo in the Udmurt Republic, Russian Federation. ${ }^{8}$ In the countries of the former Soviet Union, the style called "folk" is closely associated with traditional cultural expressions characteristic for rural areas. Buranovskiye Babushki adapt Udmurt folk songs and wear the traditional rural apparel of their region. The Newfoundland "Buranovskiye Babushki" were comprised of two middle-aged females. They wore sleeveless dresses on top of embroidered shirts, a traditional attire characteristic for many regions of rural Russia. While these clothes did not specifically represent Udmurt culture, they nonetheless conveyed the "folk" aura of the actual band. Moreover, the visual dissonance added to the humor of the performance. The MC introduced the Newfoundland "Buranovskiye Babushki" saying:

An airplane with Buranovskiye Babushki landed in Gander recently. We tried to convince them to perform for you. However, those greedy grannies asked for such a high honorarium! We were able to convince only two of them. 
This example shows the historical trajectory of New Year from a form of "folklore for Stalin" to a Newfoundland-based symbol of regional diasporic identity, imparted with a new sense of home. The Gander Airport was not a random mention. As an active community member, the MC was well familiar with the history of post-Soviet immigration to the island and the role of the airport in the lives of many people in the audience.

At the 2012 event, the MC invited all guests (seated in small groups around tables) to introduce themselves. While originating from various former Soviet republics, the majority of attendees were ethnically Russian, Belarusian and Ukrainian. United by their Slavic roots featuring cultural and linguistic similarities, these guests either spoke Russian as their primary language or had native fluency in Russian. However, there were also ethnic Azerbaijanis, Uzbeks, and Turkmens whose Turkic cultural and linguistic heritage is distant from Russia. While they spoke Russian, it was not their primary language. In previous years, non-Slavic new settlers had not only attended the annual New Year event but also participated in its organization. Alena and Ihar especially recalled a young Azerbaijani or Armenian man who had assisted with sound equipment.

Intriguingly, when meeting with Alena and Ihar to seek feedback on my paper, they asked me to pause when I listed the ethnic origins of non-Slavic attendees. They felt that my list was incomplete, and engaged in an extensive conversation trying to remember particular individuals who had participated in the New Year parties prior to my arrival to Newfoundland (field notes, November 2019). While Alena and Ihar did not add new ethnicities to my list, their requested pause was, nonetheless, ethnographically revealing. It indicated that the overall presence of non-Slavic newcomers at the Russian New Year parties in Newfoundland had been prominent and visible.

Similar to the diasporans from the former Yugoslavia, the non-Slavic settlers participating in the Newfoundland Russian New Year parties embraced the historical heritage shared with other former Soviet citizens. However, in order to do so they had to reflect on their present-day home-region differences, reinforced by varying degrees of anti-Russian sentiment connected to postSoviet nationalization processes. In the context of the New Year celebration in Newfoundland, Russian language, folklore, and popular culture were not perceived as instruments of colonization as they are often viewed in the homeregion. They, instead, served as "linking factors." People from the former 
Soviet republics who may have been culturally and politically distant in the home-region were placed in a closer cognitive proximity on the commonalitydifference continuum in Newfoundland.

\section{Safe Folklore}

That traditions often become recontextualized in new settings under changing circumstances is not a new idea for ethnographers. ${ }^{9}$ Some folklorists, engaging with Hobsbawm and Ranger's concept of "invented tradition," conceptualize such phenomena as "usable pasts" (Tuleja 1997). While Hobsbawm and Ranger are primarily interested in macro-level top-down processes, these authors illustrate that "the politically powerless may also have the power to invent, to apply the creative impulse to their own private heritages, and in doing so to keep their own walls vibrantly renewed" (Tuleja 1997, 3). Such creative efforts are frequently observed in diasporas.

New Newfoundlanders from the post-Socialist world recontextualize their home-region folklore. Traditional local dishes of former Yugoslavian countries and Russian New Year become representative symbols of a regional diasporic identity and serve as "linking factors." What makes these two examples unique is not the settlers' creative recontextualization endeavors per se, but, rather, their selection strategies. The selection of which cultural expressions of the past are usable goes hand-in-hand with the consideration of which are unusable.

Post-Socialist newcomers share community-building efforts with people with whom bridges may have been broken in the places of origins. Thus, they need to choose those forms of expressive culture that constitute an effective diplomatic agency. What unites traditional post-Yugoslav foodways and postSoviet New Year's celebrations is their broad cross-ethnic relevance and familiarity to many people. However, what matters even more than familiarity is the safety of cultural expressions.

By safe folklore, I propose to understand those creative endeavors that do not cause tensions within a group on political, ethnic, religious or any other dividing grounds but, rather, inspire unity and peace. In contrast, unsafe folklore embraces those forms of cultural expressions that can potentially reinforce social divisions in a community. However, it is crucial to understand that folkloric safety (as well as unsafety) is a continuum. What may be considered safe is deeply situational and contextual. For example, in line with studies that focus on food as a source of political tension (for example, Fraser 20II), 
my post-Yugoslav participants often joke that it takes very little for their people to begin fighting over the ethnic ownership of particular dishes. Such sentiments could potentially acquire a more serious connotation in those contexts where the presence of specific former Yugoslavian ethnicities is extensive. In the hostregion of Newfoundland food is a safe "usable past" that serves as a diplomatic point of connection. It is a more neutral and unifying cultural expression than, for example, any religion-related tradition coming from the Balkans. Tensions between Yugoslavia's dominant religions, Orthodox Christianity, Catholicism and Islam, played one of the key roles in the Yugoslav Wars (for example, see Perica 2002). Religious folklore would be unsafe in the Newfoundland context because, due to associated historical baggage, it could potentially reinforce home-region divisions more sharply than traditional foodways.

In the case of New Year's celebrations, Russian scholars often attribute the great popularity of this holiday to its relatively mild political connotation, especially in comparison to other Soviet traditions. This is exactly what makes it an effective diplomatic tool or safe folklore in Newfoundland. Not all Soviet rituals are equally as safe. A European colleague once inquired whether postSoviet settlers in Newfoundland celebrated Victory Day. Celebrated on 9 May, Victory Day commemorates the surrender of Nazi Germany in 1945. While the anniversary years of 1965 and 1985 included military parades, the annual tradition of spectacular parades did not start in post-Soviet Russia until 1995 (Timeanddate.com).

Under the presidency of Vladimir Putin, 9 May has become "an event of mythic proportions" that glorifies Russia as a significant player on the international stage and Putin as a heroic leader (Wood 20II, I74). In Putin's Russia, Victory Day is a spectacular event involving parades showcasing Russia's military might, veterans displaying their medals, along with civilians carrying flowers and various state symbols. Perhaps the most prominent of these symbols is the orange and black ribbon of St. George. Dating back to the $18^{\text {th }}$ century Imperial Russia, it was adapted by the Soviet Union as a medal symbolizing the (Soviet) victory over Nazi Germany (Radio Free Europe 20I7).

Similar to the New Year, Victory Day took on a glorious celebratory spirit in Russia and evolved into a state-organized event widely popular at the grass roots level. It is actively celebrated in the Russian diaspora, including in larger centres in Canada. For example, the organization "The Immortal Regiment - Montreal" organizes annual processions and concerts. Two thousand people reportedly 
participated in the 2019 event, carrying flags of Russia and other former Soviet republics, along with portraits of family members who had served as soldiers, all adorned with ribbons of St. George (TASS: Russian News Agency 2019).

While celebrations are successfully organized in larger diasporic settings where many share similar political beliefs, Victory Day would be a good example of unsafe folklore and an unusable past for the small host-region of Newfoundland. As a politically charged holiday, it would not be an effective vehicle for "everyday diplomacy" but would, rather, reinforce divisions within the post-Soviet diaspora. While it may appear attractive to some post-Soviet, and especially Russian, newcomers, it could potentially cause resistance from others, including some other Russians. A number of my interviewees, while considering 9 May as a day that unites all former Soviet citizens, perceive it as a memorial day rather than a glorious holiday. They are critical of the way the current regime in Russia has appropriated Victory Day to use as a vehicle for political propaganda.

In Newfoundland the ribbon of St. George could potentially be seen as a contested symbol considering the current political dynamics in the homeregion. In Ukraine, the ribbon has become politically charged symbol associated with the annexation of Crimea and Russia's reported involvement in the military unrest in the Donbas region, resulting in a new law banning its display (Radio Free Europe 20I7). It is likely that any attempt to publicly celebrate Victory Day in Newfoundland would evoke resistance from those Ukrainian diasporans and other post-Soviet settlers who hold a negative view of any aggressive actions by the current Russian leadership.

The annual New Year's event eventually lost its safe status in Newfoundland, and ceased to continue beyond the year of 2012. This can be seen as a diplomatic strategy of silence developed by the core Russian-speaking community in response to the ongoing Ukraine-Russia conflict that began in 20I3. The crisis not only politically divided the larger post-Soviet diasporic community, but also caused tensions among close relatives and friends within the smaller Slavic cohort. Anthropologist Fredrik Barth's seminal work on ethnicity and ethnic groups helps shed light on this situation (1998). Challenging his predecessors' views, Barth emphasizes that ethnic boundaries (similar to Bauman's "differential identities") that represent the core of a sense of ethnic belonging, are neither exclusively culture-related nor static categories. They are dynamic social processes that constantly change under various influences. The conflict between Ukraine and 
Russia significantly undermined the notion of Ukrainian-Russian brotherhood perpetuated by the Soviet regime through its propagandistic emphasis on "linking factors" meant to blur ethnic divides. The conflict reinforced the boundaries and sharpened antagonistic sentiments between those who now feel strongly proUkraine or pro-Russia.

As this crisis is close to the Slavic diasporans' lives, it is impossible to look at it through the prism of "historical distance" (Philips 2013) and, thus, reflect upon it and reconcile. Considering the differences reinforced by current bloodshed in the home-region, the celebratory unifying spirit of the New Year event lost its relevance in the diaspora. (Moreover, the core organizes lost enthusiasm for public events overall). The strategy of silence became the only suitable diplomatic move. Alena mentioned in this regard: "We decided to never try to prove anything to anybody in order to not ruin our community which is difficult to gather to start with. Tomorrow, let's say, the politicians will make a deal [reach a consensus] and we may be left [with a ruined relationship]" (Alena and Ihar, interview, May 2015). The historical path of the Newfoundland Russian New Year's celebration is another example of folkloric safety as a dynamic and deeply situational entity.

\section{Host-Region: Concluding Remarks}

In contrast to the majority of diaspora studies focusing on centres with prominent diasporic presence, this paper draws attention to smaller places like Newfoundland. The case of post-Socialist diasporas on the island makes the broad notion of hostland that circulates in many diaspora studies inapplicable. The unique trajectories of (temporary) group formations and the role of difference and safe folklore in these processes show that the concept of host-region could provide a more suitable framework.

While the present study reveals how specific socio-cultural dynamics in small places can push the notion of ethnicity to the margins of diasporic group formation processes, the concept of host-region may have broader implications, not necessarily related to size or cross-ethnic diasporic interactions. Hostlands are often not homogeneous units but embrace diverse constituencies that can be formally recognized, vernacularly perceived or both. In the Canadian context, the country itself is officially defined as a number of distinct regions, namely, the Atlantic Provinces, Central Canada, the Prairie Provinces, the West Coast, and the Northern Territories (Government of Canada). Each area is associated with unique political, economic, and cultural identities. Regional identities linked to 
either the above areas or individual provinces are recognized and communicated in multiple ways, including via media and scholarly research. One example is a segment that appeared on a national broadcast of the television comedy "This Hour Has 22 Minutes" entitled "Canada: The Board Game." A narrator's voice advertises the game as "a mix of Risk and Monopoly that's no fun for anyone." Individual players represent particular political units and communities: Alberta, Indigenous people, Atlantic Canada, British Columbia, Quebec, and Canada. The "Canada" player acts as the game's dealer, defining the rules and controlling the flow of play. Stereotypical discrepancies in economic and cultural opportunities available to the game's "players" are exaggerated for comedic effect. It is noteworthy that in the comments section for this episode on the show's YouTube channel, unclejakeI54's remark "I thought this was a comedy show, not a documentary" received the most reaction (22 Minutes 2020).

Scholars also draw attention to Canadian regionalisms. For example, while focusing on the role of cuisine in tourism industry, geographers Atsuko Hashimoto and David Telfer discuss food-related regionalisms, finding these to be worth promoting and branding. To them, the distinct cuisines of Quebec, Ontario, Prairie Provinces, British Columbia and the North are shaped, among other factors, by regionally specific histories of immigration and local availability of produce (Hashimoto and Telfer 2006).

To provide an ethnographic example, while residing in Alberta I met an individual who often humorously referred to himself as a "UFO" or "Ukrainian from Ontario," adopting a term that had been featured on t-shirts sold at Ukrainian community venues. While it deserves a more extensive analysis, for the purposes of this discussion it is worthwhile to emphasize that this encounter shows that region-specific diasporic identities are characteristic even for single ethnicities and representative diasporic settings such as the provinces of Ontario and Alberta.

Considering these regional senses of identity that Canadians in different parts of the country communicate, it may be worthwhile to pay closer attention to the ways they shape diasporas. In contrast to its overly generalized counterpart of hostland, host-region - as a conceptual and methodological lens - may enable us to reveal more diversified nuances of diasporic experiences.

\section{Mariya Lesiv, Memorial University, mlesiv@mun.ca}




\section{Acknowledgement}

This research was supported by a Social Sciences and Humanities Research Council of Canada Insight Development Grant (Grant File Number 430-20I7-0ooo6).

\section{Notes}

- Various aspects of this paper were presented at the meetings of the International Society for Ethnology and Folklore (2019), the Folklore Studies Association of Canada (2019), the American Folklore Society (2019), and at the Diasporas: 3rd Global Inclusive Interdisciplinary Conference (Progressive Connexions, 2019).

2 Although contextually specific, similar regional fluidity in diasporic identities has been observed among other communities. One of the prominent examples is the South Asian diaspora (Rai and Reeves 2009).

3 I have conducted over 50 interviews with 63 individuals. Additional Io interviews were conducted by Christina Robarts under my supervision in 2013. I am grateful to Dale Jarvis, Naomi Barnes, Ruzhica (Rose) Samokovlija Baruh, Nataliya Bezborodova, Tingting Chen, Kathryn Crane, Grace Dow, Marissa Farahbod, Donna Norvey, Alina Sergachev, Wyatt Shibley, and Catherine Wiseman for providing help and research assistance during various stages.

${ }^{4}$ The use of real names and pseudonyms in this paper reflects my interlocutors' preferences.

${ }^{5}$ Diasporic identity formation processes in Newfoundland are different from those in larger diasporic settings even for single ethnicity-based groups that have pre-existing diaspora venues (Li 20I4).

6 The sporadic and situational nature of diasporic gatherings shaped my research focus. Thus, the issues of power and internal hierarchies that often constitute central themes in diaspora studies do not appear to be significant among post-Socialist diasporans. Such issues are more characteristic for representative diasporic centres associated with established institutions, membership and formal leadership.

7 Folklorist Frank Manning (1984) addresses the issues of difference and divisiveness while discussing the politics behind a Caribbean festival in Toronto. Manning's work deals with the representational characteristics of diasporic identities that are shaped by external perceptions. My study focuses on the lived aspects of diasporic heritage and their internal understanding. 
8 See the website of the band: https://24smi.org/celebrity/36Io8-buranovskie-babushki.html

9 I am grateful to my colleague, Diane Tye, for drawing my attention to the notion of recontextualization.

\section{References}

22 Minutes. 2020. “Canada: The Board Game.” https://www.youtube.com/watch?v=fdmMWqSf8gI (accessed 20 March 202I).

Adonyeva, Svetlana. 20I6. Dukh naroda i drugiie dukhi [The Spirit of the People and Other Spirits]. Saint Petersburg: Pal'mira.

Akenson, Donald. 1996. The Irish Diaspora: A Primer. Belfast: Queen's University of Belfast.

Baker, Catherine. 2015. The Yugoslav Wars of the I990s. London: Palgrave.

Barth, Fredrik. 1998 [1969]. "Introduction." In Ethnic Groups and Boundaries: The Social Organization of Cultural Difference, edited by Fredrik Barth, 9-38. Long Grove: Waveland Press.

Bauman, Richard. 1972. "Differential Identity and the Social Base of Folklore." In Toward New Perspectives in Folklore, edited by Americo Paredes and Richard Bauman, 3I-4I. Bloomington: Trikster Press.

Beltrame, Julian. 1984. “Gander Becoming Our Defection Capital.” The Citizen, I9 October. http://pgnewspapers.pgpl.ca/fedora/repository/pgc:I984-IO-I9-40/PDF/Page\%20PDF (accessed 20 March 202I).

Ben-Amos, Dan. 1972. "Toward a Definition of Folklore in Context." In Towards New Perspectives in Folklore, edited by Americo Paredes and Richard Bauman, 3-19. Austin: University of Texas Press.

Bieber, Florian. 2015. “The Serbia-Kosovo Agreements: An EU Success Story?” Review of Central and East European Law 40: 285-319. https://doi.org/IO.II63/15730352-04003008.

Bielenberg, Andy, ed. 200o. The Irish diaspora. Harlow, UK: Longman.

Bruner, Edward. 1996. "Tourism in Ghana: The Representation of Slavery and the Return of the Black Diaspora." American Anthropologist 98 (2): 290-304. https://www.jstor. org/stable/682888

Bulmer, Martin and John Solomos, eds. 20II. Diasporas, Cultures and Identities. New York: Routledge.

Brubaker, Rogers. 2005. “The 'Diaspora' Diaspora.” Ethnic and Racial Studies 28 (I): I-I9. 
Cawley, Janet. 1985. "Defectors Take Wing During Fuel Stopover." Chicago Tribune, II April. https://www.chicagotribune.com/news/ct-xpm-1985-04-II-8501210193-story. html (accessed 20 March 202I)

CBC News. 1999. "Yugoslavian Refugees In Nfld Agonize Over Balkan Events." 9 April. https://www.cbc.ca/news/canada/yugoslavian-refugees-in-nfld-agonize-over-balkanevents-I.I8097I (accessed 20 March 202I).

CBC News. 2016. "The Free World Features Bulgarian Artists Who Defected In N.L. and Stayed." 20 June. https://www.cbc.ca/news/canada/newfoundland-labrador/ bulgarian-art-st-john-s-rooms-I.3642027 (accessed 20 March 202I).

Chinn, Jeff. 1996. Russians As the New Minority: Ethnicity and Nationalism In the Soviet Successor States. Boulder, CO: Westview Press.

Chowdhury, Amitava. 2016. "Between Dispersion and Belonging: At Home in the Diaspora." In Between Dispersion and Belonging: Global Approaches to Diaspora in Practice, xi-xvi. Montreal: McGill-Queen's University Press.

Chowdhury, Amitava and Donald H. Akenson. 2016. Between Dispersion and Belonging: Global Approaches to Diaspora in Practice. Montreal: McGill-Queen's University Press.

Clifford, James. 1994. "Diasporas." Cultural Anthropology 9 (3): 302-338. https://doi.org/ IO.I525/can.1994.9.3.02a00040.

Cohen, Robin. 2008. Global Diasporas: An Introduction. 2nd Edition. London: Routledge.

Cojocaru, Natalia. 2006. "Nationalism and Identity in Transnistria." Innovation 19 (3/4): 26I-272. https://doi.org/I0.I08o/13511610601029813.

Delisle, Jennifer Bowering. 2013. The Newfoundland Diaspora: Mapping the Literature of Out-Migration. Waterloo: Wilfrid Laurier University Press.

Dufoix, Stéphane. 2008. Diasporas. Translated by William Rodarmor. Berkeley: University of California Press.

Dundes, Alan. 1965. "What is Folklore?" In The Study of Folklore, edited by Alan Dundes, I-3. Englewood Cliffs, N.J.: Prentice-Hall.

Dushechkina, E. V. 2003. "Ded Moroz i Snegurochka" [Father Frost and Snegurochka]. Otechestvennyie Zapziskzi 2003 (I). http://www.strana-oz.ru/2003/I/ded-moroz-isnegurochka (accessed 20 March 202I).

Fialkova, Larisa and Maria Yelenevskaya. 2013. In Search of the Self: Reconciling the Past and the Present in Immigrants' Experience. Tartu: ELM Scholarly Press. 
Fraser, Joy. 20II. "A Taste of Scotland: Representing and Contesting Scottishness in Expressive Culture About Haggis." PhD dissertation, Memorial University of Newfoundland.

Georges, Robert. 1980. Greek-American Folk Beliefs and Narratives. North Stratford, NH: Ayer Co Pub.

Gilad, Lisa. 1990. The Northern Route: An Ethnography of Refugee Experiences. St. John's: Memorial University of Newfoundland.

Government of Canada. 20I2. "Discover Canada-Canada's Regions." https://www. canada.ca/en/immigration-refugees-citizenship/corporate/publications-manuals/ discover-canada/read-online/canadas-regions.html (accessed 20 March 202I).

Gray, Breda. 2004. Women and the Irish Diaspora. Abingdon, Oxon, UK: Psychology Press. Green, Charles. 1997. Globalization and Survival in the Black Diaspora: The New Urban Challenge. Albany: State University of New York Press.

Greenhill, Pauline. 2002. "Folk and Academic Racism: Concepts from Morris and Folklore." Journal of American Folklore II5 (456): 226-246. https://doi.org/IO.2307/4I2922I.

Hashimoto, Atsuko and David Telfer. 2006. "Selling Canadian Culinary Tourism: Branding the Global and the Regional Product." Tourism Geographies 8 (I): 3I-55.

Heleniak, Timothy. 2017. "Diasporas, Development, and Homelands in Eurasia After 199I." In Post-Soviet Migration and Diasporas: From Global Perspectives to Everyday Practice, edited by Milana V. Nikolko and David Carment, II-27. Cham, Switzerland: Palgrave Macmillan.

Hudgins, Sharon. 20II. "Buttering Up the Sun: Russian Maslenitsa From Pagan Practice to Contemporary Celebration." In Celebration: Proceedings of the Oxford Symposium on Food \& Cookery, edited by Mark McWilliams, I4I-150. London: Prospect Books.

Huxtable, Simon, Sabina Mihelj, Alice Bardan and Sylwia Szostak. 2017. "Festive Television in the Socialist World: From Media Events to Media Holidays." Journal of Popular Television 5 (I): 49-67. https://doi.org/IO.I386/jptv.5.I.49_I.

Isurin, Ludmila. 20II. Russian Diaspora: Culture, Identity, and Language Change. Berlin: Walter de Gruyter.

Iunusov, A. S. 2003. "Migration in Post-Soviet Azerbaijan." Russian Politics and Law 4I (3): 69-83. https://doi.org/I0.2753/RUPIO6I-19404I0369.

Jackson Anderson, Willow. 2012. "Immigration in Rural Newfoundland: Individual and Community Change." PhD dissertation, The University of New Mexico. 
Kishinevsky, Vera. 2004. Russian Immigrants in the United States: Adapting to American Culture. New York, NY: LFB Scholarly Publishing LLC.

Khanenko-Friesen, Natalia. 20II. Inshyi svit abo etnichnist' u dii: Kanads'ka ukrains'kist' kintsia 2oho stolittia [The Other World Or Ethnicity in Action: Canadian Ukrainianness at the End of the $20^{\text {th }}$ Century]. Kyiv: Smoloskyp.

Khanenko-Friesen, Natalia. 20I7. "Migrant Self-Reflectivity and New Ukrainian Diaspora in Southern Europe." In Post-Soviet Migrations and Diasporas: From Global Perspectives to Everyday Practices, edited by Milana V. Nikolko and David Carment, 47-64. Cham, Switzerland: Palgrave Macmillan.

Klymasz, Robert. 1980. Ukrainian Folklore in Canada: An Immigrant Complex in Transition. New York: Arno Press.

Kolstoe, Paul. 1995. Russians in the Former Soviet Republics. London: Hurst.

Kolstø, Pål. 200I. "Russian Diasporas in the 'Near Abroad': Implications for International Peace." Diaspora: A Journal of Transnational Studies Io (2): 297-305. I0.1353/ dsp.20II.0044.

Köngäs-Maranda, Elli-Kaija. 1980. Finnish-American Folklore: Quantitative and Qualitative Analysis. New York: Arno Press.

Kruglova, T. and N. Savras. 20I0. "Novyi god kak prazdnichnyi ritual sovetskoi epokhi” [New Year As a Celebratory Ritual of the Soviet Epoch]. Iskusstvovedenie i kul'turologiia. http://elar.urfu.ru/bitstream/I0995/I8592/I/iurg-20IO-76-oI.pdf.

Laguerre, Michel S. 2006. Diaspora, Politics, and Globalization. New York: Palgrave Macmillan.

Laitin, David D. 2004. “The De-Cosmopolitanization of the Russian Diaspora: A View from Brooklyn in the 'Far Abroad." Diaspora: A Journal of Transnational Studies I3(I): 5-35. I0.I353/dsp.2006.0006.

Lattanzi Shutika, Debra. 20II. Beyond the Borderlands: Migration and Belonging in the United States and Mexico. Berkeley, CA: University of California Press.

Lauristin M. and M. Heidmets. 2002. The Challenge of the Russian Minority. Tartu: Tartu University Press.

Lawless, Elaine. 1993. Holy Women, Wholly Women: Sharing Ministries of Wholeness Through Life Stories and Reciprocal Ethnography. Philadelphia: University of Pennsylvania Press. 
Levy, André and Alex Weingrod, eds. 2005. Homelands and Diasporas: Holy Lands and Other Places. Redwood City, CA: Stanford University Press.

Manning, Frank. 1984. "Carnival in Canada: The Politics of Celebration." In The Masks as Play, edited by Brian Sutton-Smith and Diana Kelly-Byrne, 24-33. New York: Leisure Press.

Marsden, Magnus. 20I6. "We Are Both Diplomats and Traders: Afghan Transregional Traders Across the Former Soviet Union." The Cambridge Journal of Anthropology 34 (2): 59-75. https://doi.org/I0.3I67/ca.2016.340205.

Marsden, Magnus, Diana Ibañez-Tirado and David Henig. 2016. "Everyday Diplomacy: Introduction to Special Issue." The Cambridge Journal of Anthropology 34 (2): 2-22. https://doi.org/I0.3I67/ca.20I6.340202.

Miller, Frank. 1990. Folklore for Stalin: Russian Folklore and Pseudofolklore of the Stalin Era. Armok, NY: M. E. Sharpe.

Moghissi, Haideh, ed. 2006. Muslim Diaspora: Gender, Culture and Identity. Abingdon, UK: Routledge.

Nahachewsky, Andriy. 2002. "New Ethnicity and Ukrainian Canadian Social Dances." Journal of American Folklore II5 (456): I75-190. I0.2307/4I292I8.

Naimark, Norman M. and Holly Case. 2003. Yugoslavia and Its Historians : Understanding the Balkan Wars of the I990s. Stanford: Stanford University Press.

Noyes, Dorothy. 1995. "Group.” Journal of American Folklore I08 (430): 449-478. https:// doi.org/I0.2307/541656.

Overton, James. 1996. "Promoting the Real Newfoundland." In Making a World of Difference: Essays on Tourism, Culture, and Development in Newfoundland, IOI-I23. St. John's: ISER.

Pechurina Anna 20I7. "Post-Soviet Russian-Speaking Migration to the UK: The Discourses of Visibility and Accountability." In Post-Soviet Migration and Diasporas: From Global Perspectives to Everyday Practice, edited by Milana V. Nikolko and David Carment, 29-45. Cham, Switzerland: Palgrave Macmillan.

Parekh, Bhikhu, Gurharpal Singh and Steven Vertovec, eds. Culture and Economy in the Indian Diaspora. London: Routledge, 2003.

Perica, Vjekoslav. 2002. Balkan Idols: Religion and Nationalism in Yugoslav States. Oxford: Oxford University Press.

Philips, Mark S. 20I3. On Historical Distance. New Haven: Yale University Press. 
Pocius, Gerald. 2000. A Place to Belong: Community Order and Everyday Space in Calvert, Newfoundland. Montreal: McGill-Queen's University Press.

Radio Free Europe. 20I7. “Ukraine Bans Russian St. George Ribbon.” I2 June. https:// www.rferl.org/a/ukraine-bans-russian-st-george-ribbon/28542973.html (accessed 20 March 202I).

Rai, Rajesh and Peter Reeves, eds. 2009. The South Asian Diaspora: Transnational Networks and Changing Identities. London: Routledge.

Remennick, Larissa. 2012. Russian Jews on Three Continents: Identity, Integration and Conflict. Livingston, NJ: Transaction Publishers.

Rozen, Minna. 2008. Homelands and Diasporas: Greeks, Jews and their Migrations. London: I.B. Tauris.

Ruberto, Laura and Joseph Sciorra, eds. 20I7. New Italian Migrations to the United States. Urbana: University of Illinois Press.

Satzewich, Vic. 2003. The Ukrainian Diaspora. London: Routledge.

Shlapentokh, Vladimir, Munir Sendich and Emil Payin. 1994. The New Russian Diaspora: Russian Minorities in the Former Soviet Republics. Armonk, NY: M.E. Sharpe.

Shuman, Amy. 1993. “Dismantling Local Culture.” Western Folklore 52: 345-364. doi:I0.2307/I500094.

Smith, Hazel and Paul Stares, eds. 2007. Diasporas In Conflict: Peace-makers or Peacewreckers? Tokyo: United Nations University Press.

Solari, Cinzia. 20I7. On the Shoulders of Grandmothers: Gender, Migration and Post-Soviet Nation-State Building. Abingdon: Routledge.

Stokes, Gale. 2005. "From Nation to Minority Serbs in Croatia and Bosnia at the Outbreak of the Yugoslav Wars." Problems of Post-Communism 52 (6):3-20. https:// doi.org/I0.I080/10758216.2005.II052224.

TASS: Russian News Agency. 2019. "More than 2,000 people took part in 'Immortal regiment' in Montreal” 9 April. https://tass.com/society/IO57709 (accessed 20 March 202I).

Timeanddate.com. "Victory Day in Russia." https://www.timeanddate.com/holidays/ russia/victory-day (accessed 20 March 202I).

Thorne, Cory. 2007. "Gone to the Mainland and Back Home Again: A Critical Approach to Region, Politics, and Identity in Contemporary Newfoundland Song." Newfoundland and Labrador Studies 22 (I): 5I-73. https://journals.lib.unb.ca/index.php/NFLDS/article/ view/I0097/I0352. 
Toelken, Barry. 1979. The Dynamics of Folklore. Boston: Houghton Mifflin Company.

Tölölyan, Khachig. 20I2. "Diaspora Studies: Past, Present and Promise.” International Migration Institute Working Papers 55.

Tziovas, Dimitris, ed. 2016. Greek Diaspora and Migration Since I7oo: Society, Politics and Culture. London: Routledge.

Tuleja, Tad, ed. 1997. Traditions and Group Expressions in North America. Logan, UT: Utah State University Press.

Valenta, Marko and Sabrina Ramet, eds. 20II. The Bosnian Diaspora: Integration in Transnational Communities. Farnham: Ashgate.

Winland, Daphne. 1995. "We Are Now an Actual Nation': The Impact of National Independence on the Croatian Diaspora in Canada." Diaspora: A Journal of Transnational Studies 4 (I): 3-29. https://doi.org/IO.3I38/diaspora.4.I.3.

Wood, Elizabeth A. 20II. "Performing Memory: Vladimir Putin and the Celebration of WWII in Russia." The Soviet and Post-Soviet Review 38: I72-200. https://doi. org/I0.II63/I876332IIX59II75.

Yekelchyk, Serhy. 2015. The Conflict in Ukraine: What Everyone Needs to Know. New York: Oxford University Press.

Zabrodskaja, Anastassia and Martin Ehala. 20I4. "Inter-Ethnic Processes in Post-Soviet Space: Theoretical Background." Journal of Multilingual and Multicultural Development 35 (I): I-8. https://doi.org/IO.IO80/OI434632.2013.845194. 